KUDÜS'ÜN ȘAHITLIĞi

\title{
Mahmut UYAN*
}

Öz: Kadim ve kutsal bir şehir olan Kudüs, kurulduğundan günümüze kadar birçok medeniyete kucak açmış ve birçok medeniyeti etkilemiştir. Birçok devletin hükümdar ve komutanı onu ele geçirmeye çalışmış ya da ele geçirmiştir. Bunlardan başlıcaları: Mısırlılar, Babiller, Sasaniler, Romalılar, Müslümanlar, Haçlılar ve son olarak Siyonist Yahudilerdir. Bunlardan kimisi kutsal şehri yakıp yıkarken ve ahalisini katlederken, kimisi ise onun kutsiyetine saygı gösterip barış yurdu olma özelliğini muhafaza etmiş ve ahalisine merhamet göstermiştir. Başta Mescid-i Aksa'nın taşları olmak üzere Kudüs'ün her bir taşı bunların zihniyet farklılığına ve bu zihniyet farklılığının yansımalarına şahitlik etmiştir/etmektedir. Bu çalışmada Kudüs şehrinin kuruluşundan en son 1187 yılında Selahaddin Eyyubi tarafından fethine kadar ona hâkim olan ve hâkim olmak isteyenlerin tarihi karşılaștırmalı olarak ele alınacaktır. Bu karşılaştırmada Haçlıların 1099 yılında Kudüs'ü istila etmeleri ile Selahaddin Eyyubi'nin 1187 yılında fethetmesi üzerine daha çok durulacaktır. Bu yapılırken hem batılı hem de doğulu kaynaklara müracaat edilecek. Onlar bir bakıma Kudüs'ün hem şahitliğine ışık tutacak hem de ona tercüman olacaktır. Bunun için de onlardan doğrudan alıntı yapmaktan kaçınılmayacaktır.

ANAHTAR KELIMELER: Beytülmakdis, Kudüs, Selahaddin Eyyubi, Zihniyet.

\section{The Testimony of al-Quds}

ABSTRACT: Bayt al-Maqdis/ al-Quds, an ancient and holy city, has embraced many civilisations since its formation. The rulers and commanders of many states have tried to seize or have control over it. These include the Egyptians, Babylonians, Sassanid, Romans, Muslims, Crusaders and more recently, Zionist Jews. While many of them burned down the holy city to the ground and massacred its inhabitants, some have respected its holiness, preserved its features and showed mercy to its people. Each stone in al-Quds, especially those of al-Aqsa Mosque, has witnessed the differences in their approaches. The history of those who dominated the holy city from its establishment until the last conquest by Saladin in 1187 will be discussed comparatively in this study. The comparison will pay more emphasis to the Crusaders' invasion in 1099 and the liberation of Saladin in 1187 through direct quotations and the use of both western and eastern sources. In a way, they will give an eyewitness account to present Bayt al-Maqdis's testimony.

KEYWORDS: Bayt al-Maqdis, Jerusalem, Salah al-Din, Attitudes.

\footnotetext{
* Mardin Artuklu Üniversitesi Lisansüstü Bilimler Enstitüsü Tarih Anabilim Dalı Doktora Öğrencisi, Mardin/
} Türkiye, mahmutuyan72@gmail.com, ORCID: 0000-0003-3110-8463. 


\section{Gíniș}

Şehirler, özne olan insanoğlunun eliyle değişik nesnelerle inşa edilip biçim alırlar. Evleri olur, içinde cadde ve sokakları uzar. Su ona ayrı bir canlılık, renklilik ve hayat katar. Fakat o şehir hâlâ nesnedir ve insan olan öznenin etkisindedir. Şehirler, belirli bir aşamadan sonra nesne olma keyfiyetine sahip olmakla beraber özne olma özelliğini de kazanır. Özne olma aşamasıyla beraber kendi öznesi olan insanı etkilemeye, onu değiştirip dönüştürmeye başlar. Şehir artık kendine has bir ruh, zihniyet ve karakter kazanmıştır. Böylece her bir şehir, onu diğer şehirlerden ayıran bir kimlik de kazanmış olur. Artık şehir, nam-ı diğer medine, kültür ve medeniyetle ünsiyet ve bağ kurarak onlarla hemhal olur ve nihayetinde kültür ve medeniyetin beşiği haline gelir. Kadim olan bazı şehirler ise sahip oldukları ayrıcalıklı özelliklerinden dolayı daha çok öne çıkarlar ve etkileri de evrensel olur.

Kadim ve kutsal olan Kudüs, yeryüzünde kurulmuş olan şehirler arasında eşsiz bir yere sahiptir. O, dünyanın kalbi olan Ortadoğu'da, Ortadoğu'nun kalbi olan Mescidi Aksa ise onun kalbinde bulunmaktadır. Ve aynı zamanda Kudüs, Yahudi, Hıristiyan ve Müslümanların kalbinde yer almaktadır. Böyle olduğu için dünya gündeminin kalbinde yer almakta, Ortadoğu ve dünya gündemini de derinden etkilemektedir.

Kudüs, ibrahimî geleneğe dayanan tevhid dininin sembol şehridir. Ruhunu ve esinini tevhid dininden alan bu şehir, tevhidî geleneği temsil eden bu medeniyetin adeta tecessümü ve canlı tanığıdır. Semavî dinlere mensup Yahudi, Hıristiyan ve Müslümanlar için kutsal olması, bu özelliğinden kaynaklanmaktadır.

Darussalem, yani Selamet yurdu olan ve olması gereken Kudüs, birçok tarihî olaya şahitlik etmiş emsalsiz bir şehirdir. Tarihinde kimisi onu şanına ve namına yakışır bir şekilde sevgi, merhamet ve itina ile kucaklayıp korumuş, kimisi ise selametine halel getirip onu yakıp yıkmış ve talan etmiştir. Bu özelliği, adeta turnusol kâğıdı gibi ona sahip olmak isteyenlerin gerçek niyet, zihniyet ve hüviyetlerini ortaya koymuştur.

Kadim ve kutsal bir kent olan Kudüs'ün özne olma özelliği, yeryüzündeki bütün diğer kentlerden farklılık arz etmektedir. Bu özelliğine binaen yeryüzündeki hiçbir kent Kudüs kadar dini-siyasi hüviyete de sahip olamamıştır. Kudüs'ün aynı zamanda hem peygamber ve hem de hükümdar olan Davud (a.s.) ve Süleyman (a.s.)' a başkentlik yapmış olması bu duruma yeterince açıklı getirmektedir.

Üç semavi din olan Yahudilik, Hıristiyanlık ve İslamiyet için kutsal olan Kudüs'ün tarihi çok eskilere dayanmaktadır (M. Ö. 3000-1200) (Gül, 2001: 1/306; Harman, 2002: 324). Kenanilerin yurdu içinde olan Kudüs, Hurriler, Yebusiler, Yahudiler, Mısırılır, Babiller, Persler, Makedonyalı İskender, Romalılar, Sasaniler, Müslümanlar, Haçlı Hıristiyanlar ve Siyonist Yahudilerin hâkimiyetine girmiştir. Kudüs, bu uzun geçmişinde sayısız istila, yıkım ve katliama maruz kalmış olmasına rağmen halen sahip olduğu özellikleriyle varlığını devam etmekte ve dini-siyasi açılardan dünyanın gündemini etkilemektedir. 
Adının geçtiği bilinen en eski ilk belge milattan önce XIX ve XVIII yüzyıllara Mısır metinleridir (Harman, 2002: 26/323). Tarihinde azımsanmayacak sayıda isme sahip olmuştur. Bütün bu isimlerin kökeninde kutsiyet ve barış manalarının olması dikkat çekicidir (Gül, 2001: 1/306-307; Harman, 2002: 323-324). Kutsal ve barış kenti olan bu kent, maalesef değişik millet ve devlet/imparatorluklar tarafından selametine halel getirilmiş ve kutsiyeti çiğnenmiştir.

Kudüs'ün başına gelenler, genel hatlarıyla Yahudilerin ve Yahudiliğin tarihini de kapsayan Eski Ahid'de geçmektedir. Yahudilerin Filistin'e gelmeleriyle başlayan süreçle beraber Kudüs, Yahudilerin hayatında merkezi role sahip olmuş ve bu durum tarihlerine yansıyıp tarihlerini çok yönlü etkilemiştir.

\section{KUDÜS'ÜN YAȘADIĞI BELLI BAȘLI OLAYLARIN KRONOLOJisi}

\section{Yahudilerin Kudüs'ü Yakmaları}

Kudüs, Yahudiler için kutsal bir kenttir. Buna rağmen Kudüs'e saldırıp onu yakanlar arasında Yahudiler de vardır. Yahudilerden iki kabile olan Yahuda ve Simon kabileleri Kudüs'e saldırıp kralı esir almış ve şehri yakmışlar (Hakimler, 1/104). Daha ileriki bir tarihte bir İsrail kralı Kudüs'ü ve mabedi talan emiştir. (Montefiore, 2016: 35).

\section{Mısır Kralının Kudüs'e savaş açması ve şehri yağmalaması}

Süleyman'ın oğlu Rehoboam'ın kral olduğu zamanda Mısır Kralı Şişak Kudüs'e savaş açmış, mabedin ve kral evinin hazinelerini alıp götürmüştür (I. Krallar, s. 14/26-27; Montefiore, 2016: 33). Yaklaşık seksen yıl sonra şehir tekrar yağmalanmıştır (II. Tarihller, s. 20/17).

\section{Yahudi Kuzey Krallığının Kudüs'e Saldırması}

Yahudi Kralı Amatsya'nın saltanatında kuzey Krallığı'nın kuvvetleri Kudüs'e girmiş, Kudüs duvarının bir kısmını yıkmış, mabetteki ve kral evindeki değerli eşyayı almıştır (II. Krallar, s. 14/11-149).

\section{Babillerin Aralıklarla Üç defa Kudüs'e Saldırmaları'}

Babil kralı Nebukadnezzar (Buhtunnasır) aralıklarla üç defa Kudüs'e girmiştir. Nebukadenzzar üçüncü girişinde Kudüs'ü yakıp tahrip etmek ve zenginliklerini almakla yetinmeyerek, Yahudileri de sürgüne göndermiştir. Kudüs, elli yıl boyunca harabe halinde kalmıştır. Yahudilerin sürgüne gönderilmesi, tarihlerinde bir dönüm noktası olmuştur. Bu sürgün Yahudilerde dini, kültürel, toplumsal, psikolojik vs. derin izler bırakmıştır (Krallar, s. 25).

\section{Kudüs'ün Değişik Milletlerin Hâkimiyetine Girmesi}

5.1. Babil esaretinden sonra Kudüs Milattan önce 538 yılında Pers hâkimiyetine girmiştir.

5.2. Perslerden sonra (m.ö.332), Makedonyalı Büyük İskender Kudüs'ü almıştır.

5.3. Büyük İskender'den sonra Kudüs'e Mısırlı Ptolemaioslar, daha sonra 198'den itibaren Selefikler (Selevkoslar) şehre hâkim olmuşlardır. 
5.4. Milattan önce 168'de Antiochus (Antiokkhos) IV. Epiphanes, Yunan ilahlarının heykellerini koymak suretiyle mabedi kirletmiş, bunun üzerine Makkabi isyanları başlamış ve mabed temizlenmiştir.

5.5. Milattan önce 63 yılında Pompeus Kudüs'ü işgal etmiş, şehri kuşatan duvarların bir kısmını yıktırmıştır.

5.6. Crassus, milattan önce 54 yılında mabedi yağmalamıştır.

5. 7. Partlar, Milattan önce 40 yılında şehri ele geçirmiştir (Harman, 2002: 325).

\section{Romalıların Kudüs'ü Kușatmaları}

Babil sürgünü ilk sürgündür. Fakat son değildir. Bu sürgüne gönderilenlerden bir kısmı daha sonra dönme fırsatını bulmuşlar. Fakat Romalıların sürgüne gönderdikleri Yahudilerin dönüşü uzun süre almış ve bunun etki ve sonuçları ise birçok yönden daha derin olmuştur.

Romalılar Kudüs'e saldırmadan önce şehirde iç savaş hüküm sürüyordu. Yahudilerden üç farklı güç birbirleriyle savaşarak hem şehri tahrip ediyorlardı hem de birbirlerini öldürüyorlardı. Romalıların şehre yaklaşmalarıyla iç savaşa son verip birleşmelerine rağmen hiçbir sonuç vermemiştir (Montefiore, 2016: 127-128).

\footnotetext{
“Milattan sonra 70 yılında Romalı kumandan Titus Kudüs'ü kuşatmış, bu sırada mabed ve hemen hemen bütün şehir yanmıştır. Titus, Batı duvarındaki bir bölüm ve üç kule hariç duvarları yıktırmıştır” (Harman, 2002: 325).

"Şehir yerle bir edilip içindekiler katledildikten birkaç hafta sonra Titus tekrar Kudüs'ten geçti, onun melankolik harabelerini geçmişteki ihtişamıyla kıyasladı. Sonra ele geçirdiği Yahudi liderler, metresi Berenice, gözde destekçisi Josephus ve Tapınak'ın hazineleriyle birlikte Roma'ya yelken açtı" (Montefiore, 2016: 131).
}

\section{Romalıların Kudüs'ün Harabeleri Üzerine Bir Putperest Şehir Kurmaları}

Tevhid geleneğinin sembol şehri ve kıblegahı olan Kudüs şehri putperest Romalılar tarafından asli kimliğinden arındırılarak bir putperest şehri haline getirilmek istenmiştir. Bunun için Romalılar şehrin ismini Aelia (Ar. İliya) olarak değiştirmişler ve Allah'a ibadet amacıyla kurulan mabedlerin yerinde ise putperestliğe ait tapınak inşa etmişlerdi. Şehre girmek isteyen Yahudilere ise ölüm cezası konulmuştur. (Harman, 2002: 3259).

\section{Sasanilerin Kudüs'e Saldırmaları}

Sasanilerin Kudüs'e saldırmaları İslamiyet'in zuhurundan sonra olmuştur. M.S. 614 yılında Sasaniler'in yaptığı saldırı, Mekke müşriklerin ve Müslümanların gündemine de yansımıştır. Rum Süresinin giriş bölümü bu konu ile ilgilidir (Rum Süresi, 30/1-7).

Bu saldırıda dünyanın iki güçlü imparatorluğu Roma ve Sasaniler karşı karşıya gelmişler. Resmi dini Hıristiyanlık olan Roma İmparatorluğu şehri korurken, diğer yandan resmi dini Zerdüşlük olan Sasani İmparatorluğu ise şehre saldırıda bulunmuştur. Semavi dine mensup olan Yahudiler ise bu çatışmada Sasanilerle beraber kendisi gibi semavi dine mensup Hıristiyanlarla savaşmış ve onları katletmişlerdir. Böylece Kudüs'ün merkezde olduğu bir savaş ve bu savaşta 
dünyanın iki büyük imparatoru ile üç farklı din çarpışmıştır. Bir tarafta saldırgan Zerdüşt dinine mensup olan Sasaniler ile Yahudiler, diğer tarafta ise şehirle beraber saldırıya maruz kalan Hıristiyan Romalılar.

Runicman, Sasaniler'in Kudüs'e saldırıp yaptı̆̆ı katliam ve şehri ateşe vermeleri ile ilgili şunları kaydetmektedir:

\begin{abstract}
"Patrik Zacharias kan dökülmesinden kurtulmak için şehri teslim etmeye hazırdı; fakat şehrin Hristiyan mukimleri bu kadar kolay pes etmeyi kabul etmedi. Mayısın 5 'inde, içerdeki Yahudilerin yardımıyla, Persler şehre girmeyi başardı. Bunu son derece korkunç sahneler izledi. Hristiyanların ev ve kiliseleri ateşe verildi; kimi Pers askerleri, çoğunluğu da Yahudiler tarafından ayırt edilmeksizin katledildi. 60.000 kişinin hayatını kaybettiği söylenir ve 35.000'den daha fazlası da köle olarak satıldı. Şehrin kutsal kalıntıları, Kutsal Haç ve Mesih'in silahları saklanmıştı fakat ortaya çıkarıldı ve Patrik'le birlikte, Perslerin Hristiyan kraliçesi, Nasturi Meryem'e hediye olarak gönderildi. Şehir ve civarındaki yıkım o kadar büyüktü ki, bugüne kadar, kırsal kesim tam olarak kendine gelmedi" (Runciman, 1990: 1/10).
\end{abstract}

Burada ironi olan husus, Yahudilerin rolüdür. Onlar, tarihleri boyunca madalyonun iki farklı yüzü gibi iki zıt hali yaşamışlardır. Belirli bir zaman kesitindeki bir olayda mazlum durumundayken, başka bir zaman kesitindeki olayda ise zalim oluyorlar. Bu olayda Yahudiler, Sasani askerleri ile beraber Kudüs'teki Hıristiyanları katlediyorlar. Fakat sadece on altı yıl sonra Kudüs'e giren Hıristiyan Bizans İmparatoru Heraklius, Yahudileri affedeceğine dair söz vermesine rağmen, Kudüs'teki Yahudilerin bir kısmını sürmüş, pek çoğunu öldürmüş ve kalan Yahudilerin ise Hristiyan olmalarını emretmiştir (Montefiore, 2016: 169).

\title{
9. Müslümanların Kudüs'ü Fethi
}

Kudüs, Müslümanlar tarafından Hz. Ömer'in hilafeti zamanında Miladi 638 tarihinde fethedilmiştir. Bu tarihten başlayarak Haçlıların 1099 yılında Kudüs'ü işgaline kadar Müslümanların hâkimiyetinde kalmıştır.

Hz. Ömer, Kudüs'ü kutsiyetine ve şanına yakışır bir itina ile almıştır. Kudüs'ü alırken, Müslüman olmayan ahalisine merhamet ve adaletle davranmıştır. Bu yaklaşımı ve uygulaması, onun sahip olduğu zihniyetin gereği ve yansımasıydı; tıpkı örnek aldığı Peygamberin Mekke'yi fethettiğinde gösterdiği merhamet gibi. Rahmet Peygamberi ve onu örnek alan Hz. Ömer kişisel hırs ve intikam peşinde olmadıklarından merhamet yolunu seçmişlerdir.

Runciman, Hz. Ömer'in Kudüs'ün fethiyle ilgili şunları aktarmaktadır:

“638 senesinin bir şubat gününde, Halife Ömer beyaz bir deve üzerinde Kudüs’e girdi. Oldukça kirli, yıpranmış bir cübbe giymişti ve onu izleyen ordusu kaba ve dağınıktı; fakat disiplini mükemmeldi. Teslim olan şehrin Patriği Sophorious onun tarafındaydı. Ömer atını doğrudan arkadaşı Muhammed'in göğe yükseldiği Süleyman tapınağına doğru sürdü. Halifeyi orada dikilirken izleyen Patrik, İsa'nın sözlerini hatırladı ve gözyaşları içinde sayıkladı: 'Peygamber Daniel'in sözünü ettiği yıkıcı şeyin kutsal yerde dikildiğini gördüğünüz zaman'

Ardından, Halife Hristiyanların mabedini görmek istedi. Patrik onu kutsal Kabir kilisesine götürdü ve oradaki her şeyi gösterdi. Onlar kilisedeyken namaz vakti 
yaklaşmıştı. Halife seccadesini nereye serebileceğini sordu. Sophronius olduğu yerde kalması için çok ısrar etti; fakat Ömer fanatik takipçilerinin namaz kıldığı yeri İslam için alabileceği korkusuyla dışarı, porch of the Martyrion'a çıktı. Aslında korktuğu gibi de oldu. Porch Müslümanların himayesine geçti fakat kilise olduğu gibi kaldı.

Bu durum şehrin teslim şartlarına uygundu. Peygamber kendisi, putpereste ölüm ile ihtida arasında tercih sunulmalıyken, ehl-i kitab olan Hristiyan ve Yahudilerin (buna sonrada peygamberin izniyle Zerdüştler de eklenmişti.) ibadethanelerini korumaları izin verilmesi gerektiğini buyurmuştu fakat daha fazla inşa edemezler ne silah taşıyabilir ne de ata binebilirlerdi ve cizye denen özel bir vergi ödemeliydiler. Sophranious atına binip Zeytin dağında Halife'yi karşılamaya gittiğinde bundan daha iyi şartlar umamazdı"(Runciman, 1990: 3-4; Montefiore, 2016: 178-180; Demirkent, 1997: 55).2

Hz. Ömer, Patrik Sophronius ile yaptığı anlaşmaya göre, Hıristiyanların canları, malları, kilise ve haçları için emniyet garantisi veryor; inanç konusunda onlara hiçbir baskı olmayacak diyordu (Demirkent, 1997: 55).

\section{Haçlıların Kudüs'ü İşgal Etmeleri}

Haçlı Seferleri 1096 yılında başlamış, 1291 yılında ise Memluk devleti tarafından Müslüman topraklardaki varlığına son verilmiştir. İki asra yakın devam eden Haçlı Seferleri'nin Müslüman topraklardaki varlığı 1291'de bitmişse de Batı Katolik Hıristiyan dünyasında zihniyet, niyet ve ruh olarak devam etmiştir/etmektedir.

Haçlı Seferlerinin dahili ve harici olmak üzere iki temel amacı vardı. Bu iki amacın ortak özelliği ise Katolik dünyanın ruhani lideri papanın hakimiyetini ve mutlak otoritesini hem Avrupa'da hem de Anadolu ve Yakın Doğu'da tesis etmekti. Papanın Anadolu'ya ve Yakın Doğu'ya hakim olması, Avrupa'nın buralara hakim olması anlamına geliyordu. (Demirkent, 1997:1,8). Hedefte ise buralara hakim olan Müslümanlar vardı. Müslümanların hakim olduğu bu sınırlar içinde en önemli yer ise hem Hıristiyanlar hem Yahudiler ve hem de Müslümanlar için kutsal olan Kudüs vardı.

Kudüs, Hz. Ömer'in hilafeti zamanında, 638 yılında Müslümanlar tarafından fethedilmişti. Bu tarihten 1099 yılında Haçlılar tarafından istila edilinceye kadar kesintisiz olarak Müslümanların hâkimiyetinde kalmıştır. Müslümanların hakimiyetinde geçen sürede şehirde Müslümanlarla beraber Yahudiler ve Hristiyanlar da yaşamışlardır. Hıristiyanlar, Dünya'nın değişik yerlerinden serbestçe buraya gelip haclarını Yapabilmişlerdir.

Haçlı zihniyetine sahip ve Birinci Haçlı Seferini organize eden Papa II. Urbanus ve onun liderliğinde hareket eden Avrupalı Hıristiyanlar, Müslümanları zalim halk, merhametsiz, İsa/Tanrı düşmanları, sarazen, pagan, putperest, barbar, kâfir ve günahkâr ırk olarak görüyorlardı ve gösteriyorlardı (Polat,2019: 619-622). Bu şekilde görülen/gösterilen Müslümanlar başta Kudüs olmak üzere Hıristiyanların topraklarını gasp etmiş ve Hıristiyan kardeşlerine zulmeden düşman bir halktı. Öyle ise bu düşman halk ile savaşılacak ve onlardan intikam alınacaktır. Bunun için de Avrupa Hıristiyan dünyası Papanın önderliğinde seferber olmalıdır. 
Seferin temel düşüncesi şuydu: Tanrı, bu kutsal seferi düzenleyen ve bu sefere katılanlarla beraberdi. Seferin amacı Tanrı'nın düşmanı zalim bir halk olan Müslümanlarla savaşmak ve onlardan intikam almaktı. Yapılacak savaş Tanrı'nın emrinin gereği ve meşru bir savaştı. Sefere katılanların günahları bağışlanacaktı.

Bu düşünce, Haçlıların Kudüs'te ve daha birçok yerde ortaya koydukları vahşeti ve yaptıkları katliamın perde arkasını oluşturuyordu. Haçlı kronikleri başta olmak üzere birçok batılı ve doğulu araştırmacı bu düşüncenin perde arkasını ve bu doğrultuda Haçlıların yaptığı vahşeti detaylı bir şekilde anlatmaktadır. Anlatılanlar ya bizzat olaylarda yer alanlar tarafından ya da olaylara katılanların anlatımlarına dayanmaktadır. Kudüs'te yapılan vahşeti en detaylı aktaran Haçlı kroniklerin başında Fulcherius gelmektedir.

Fulcherius, Birinci Haçlı Seferlerine katılmış bir Haçlı din adamı ve aynı zamanda kronik yazarıdır. Haçlı Seferleri fikrinin nasıl ortaya çıktığını, Patrik Urbanus'un rolü ve Haçlı seferlerine nasıl hazırlandığını kroniğinin başında açıklamaktadır. O, Haçı Seferleri fikir ve felsefesini hem anlamış hem de aynı zamanda eylem sahasında rol oynamış bir papazdır. Onun kroniği hazırlamasındaki asıl amacı, Haçlı zihniyetini, bu zihniyetin Hıristiyanlıkla ve dolayısıyla papalıkla bağlantısını ve Haçlıların bu zihniyet doğrultusunda neler yaptıklarını ve nelere katlandıklarını gelecek nesillere aktarmaktı. Aynı zamanda onun amacı, Haçlı zihniyetini ve bu doğrultuda inşa ettikleri algıyı gelecek nesillere aktarmaktı da. Bu oluşturulan algıda Tanrı kabul ettikleri İsa'ya ve dolayısıyla Hıristiyanlığa yegâne tehdit ve ortadan kaldırılması gereken asıl düşman Müslümanlar gösterilmekteydi. Bunun için Müslümanlara yönelik her türlü şiddet ve katliam meşru ve zorunlu gösterilmiştir (Carnotensis, 2009: 45-56).

Fulcherius, 1097 yılında efendisi Baudouin ile beraber Urfa'ya gitmiş, orada 1100 yılına kadar efendisi Baudouin ile kalmıştır. Baudouin'in kardeşi Kudüs Kralı Godefroi'nin ölümü üzerine, Baudouin Kudüs'ün Kralı olmak üzere Kudüs'e gitmiş ve Kudüs kralı olmuştur. Fuhcherius da efendisi ile beraber Kudüs'e gitmiştir. Böylece, Fulcherius, Kudüs Haçlılar tarafından istila edildikten bir sene sonra oraya gitmiştir. Kudüs'ün istilası ve yaşananlarla ile ilgili anlattıkları ise istila esnasında bizzat olaylara katılan Haçlılardan duymuş olduklarına dayanmaktadır. Fulcherius, Haçlıların uyguladıkları katliam ve gösterdikleri vahşeti meşrulaştırıcı ve onaylayıcı bir üslup ile aktarmaktadır:

\footnotetext{
“Böylece Haçlılar öğle vakti şehre girmeyi başardılar. Tanrı bize yardım et! Diyerek saldırıya geçen adamlarımızın ilk işi bayrağımızı surların üstüne dikmek oldu. Dehşet içindeki kâfirler ise şehrin dar sokakları boyunca kaçışıyor Haçlılar da hızla onların, peşine düşüyorlardı.

Şehrin başka bir köşesinde mücadele eden Raymond ve adamlarıysa Müslümanların surların üstünden atladıklarındı görünce olanları fark edip büyük bir sevinç içinde şehre girdiler. Biran bile duraksamadan yoldaşlarına katılıp düşmanlarını kovalamaya ve katletmeye başladılar.
} 
Bazı Araplar ve Habeşliler Davud kulesine kaçmayı başarmışlardı. Geri kalanlarsa kendilerini İsa ve Süleyman Tapınaklarına kapadılar, ancak saldırılardan kurtulamadılar.

Süleyman Tapınağının çatısından atlayarak kaçmaya çalışan Müslümanların çoğu oklarla vurularak öldürülmüştü. Bu tapınakta yaklaşık on bin Müslüman'ın boynu vuruldu. Burada olsaydınız ayak bilekleriniz katledilenlerin kanlarıyla lekelenebilirdi. Müslümanların hepsi, kadın çocuk ayırt edilmeden, katledildiler" (Carnotensis, 2009: 104).

Dini fanatizm ve para hırsı; bunlar bir araya geldi mi, vahşetin boyutundan ne dini, ne insani, ne de ahlaki hiçbir sınır kalmaz. Ve Fulcherius gibi bir din adamı da bunu normalmiş gibi görür. İnsanın hayallerini zorlayan bir vahşet sergileniyor Kudüs'te. Haçlılar, işgalden sonra şehri, maddi-manevi bütün zenginlikleriyle almaları yetmiyormuş gibi, sadece para için daha önce öldürdükleri Müslümanları bağırsaklarında sikke olur ihtimalinden, karınlarını deşiyorlar ya da aynı amaç için onları üst üste yığıp onları yakıyorlar. İlahi sevgiden ve merhametten sürekli bahseden papaz Fulcherius bu vahşeti en azından kınaması gerekirken, aksine Müslümanları paralarını saklıyorlar diye 'hilekârlıkla' suçluyor, 'iğrenç boğazlıkla' niteliyor. Ve tüm bunları ne kadar ulvi bir davaya sahip olduklarını bu dava için nelere katlandıklarını göstermek için bu satırları gelecek nesillere aktarıyor. Gelecek nesiller de atalarının yolunda giderek kapitalizm ve emperyalizmi sistemleştirerek misyonerliği de bu sistemin emrine vererek Afrika'dan Amerika'ya dünyanın değişik halklarını hem maddi ve hem de manevi olarak sömürüyorlar ve yeri geldiğinde sayısız katliama girişiyorlar. Değişmeyen bir zihniyet ve değişmeyen bu zihniyetin tüyler ürperten sonuçları. Bu zihniyet Haçlı Seferleri sonrası varlığını değişik ad ve bahanelerle sürdürdü ve halen en canlı ve kanlı bir şekilde varlığını küresel boyutta devam ettirmektedir. Yeryüzünde ifsadı yaymalarına rağmen 'biz ıslah edicileriz,' diyorlar. ${ }^{3}$

Haçlılar, Kudüs'te sınır tanımayan şiddetlerine devam ediyorlar:

"Adamlarımız ellerinde yorgun kılıçlarıyla şehrin her yanını dolaşıp hiç kimseyi ayırt etmiyor merhamet dileyenleri bile öldürüyorlardı. Halk sallanan dallardan düşen çürük elmalar ve meşe palamutları gibi hayatlarını kaybediyordu" (Carnotensis, 2009: 105).

Sizin Tanrınız mı bunu size emretti? Mabede sığınanları; kadın çocuk ve merhamet dileyenleri dahi ayrıt etmeden Kutsal ve selamet yurdu olan Kudüs'te bulunan tüm Müslümanları ve Yahudileri katletmenizi!

Gerçek fanatizm, geçek vahşet ve gerçek katliam tam da budur. Ne savaş hukuku, ne ahlak ve ne de hiçbir vicdanın asla ve asla kabul edemeyeceği şiddette bir vahşet. Bu vahşet, Üç büyük din: Yahudilik, Hıristiyanlık ve Müslümanlık için kutsal olan bir mekânda Haçlı Hıristiyanlar tarafından hunharca işleniyor ve bir din adamı olan Fulcherius, normal bir olaymış gibi bunu soğukkanlılıkla kaleme alabiliyor: "Burada olsaydınız ayak bilekleriniz kanlarıyla lekelenebilirdi." katledilenlerin Müslümanlara yönelik öyle kin, nefret ve intikamla beslenmiş bir 
algıya sahipler ki onlar için Müslümanlara yönelik her türlü vahşet normal ve meşru sayılıyor.

Runciman, Haçlıların vahşetinden bazı kesitler verdikten sonra farklı açılardan sonuçları değerlendiriyor. Kudüs'teki Yahudilerin kendi sinagoglarında yakılarak katledilmelerinin bahanesi, Müslümanlara yardım etmeleri olarak gösteriliyor. Katliamdan sonra Kudüs'te ne Müslüman ne de Yahudi kalıyor:

\begin{abstract}
"Bunca çileden sonra böyle bir zaferle çılgına dönmüş Haçlılar sokaklara, evlere, camilere akın etti, çoluk çocuk, kadın demeden karşılarına çıkan herkesi öldürdüler. Tüm gün ve gece katliam devam etti. Tancred'in savunması El-Aksa camiindeki savunmacılara koruma sağlamıyordu. Ertesi sabah erkenden bir Haçı birliği camiye girmeyi başardı ve herkesi kılıçtan geçirdiler. Raymond of Aguilers o sabah sonradan tapınağı ziyarete gittiğinde, dize kadar ulaşan kan ve cesedin arasından geçmek zorunda kaldı.

Kudüs Yahudilerinin hepsi merkez sinagoglarına kaçmıştı fakat Müslümanlara yardım etmiş sayıldılar ve kendilerine merhamet gösterilmedi. Bina ateşe verildi ve hepsi içerisinde canlı canlı yandılar. Kudüs'teki katliam tüm dünyayı derinden etkiledi. Hiç kimse kaç kişinin kurban gittiğini söyleyemiyor fakat Kudüs'ün Yahudi ve Müslüman nüfusu hiç kalmadı. Pek çok Hristiyan dahi yapılanlardan dehşete düştü; o ana dek Frenkleri zamanın karmaşık politikasında bir unsur olarak kabul etmeye hazır Müslümanlar arasında, mezkûr katliamın ardından Frenklerin bu topraklardan atılması konusunda açık bir kararlıık baş gösterdi. İslam fanatizminin geri getiren de Hristiyan fanatizminin bu kana susamış kanıtı oldu. Sonradan doğudaki daha akıllı Latinler Hristiyan ve Müslümanların ortak çalışabileceği bir zemin aramaya kalktıklarında, katliamın anısı her zaman önlerine dikildi” (Runcıman, 1990: 286-287).
\end{abstract}

Şimdi de farklı kaynaklardan derleyerek ve farklı bakış açısıyla Haçlı zihniyetini ve onun tezahürlerinin boyutlarını yine Batılı bir araştırmacı olan Montefiore'den dinleyelim:

“Tancred'in askerleri çaresiz insanlarla dolu olan kutsal avluya girdi. Oradaki çatışma saatlerce sürdü; Franklar karşılarına çıkan herkesi öldürdüler. Sadece kafa değil kurbanlarının el ve ayakların da kestiler ve her yanı kâfir kanına buladıkları için övündüler. Düşen bir şehirde katliam yaşanması alışmadık bir durum olması da bunu yapan kişilerin kendileriyle bu derece övünmeleri gerçekten de nadir bir durumdu. Görgü şahitlerinden biri olan Toulouse Kontu'nun vaizi Aguilersli Raymond manzarayı şöyle tarif etti: 'Görülmeye değer bir manzaraydı. Askerlerimiz düşmanlarının kafasını kesti, diğerlerini oklarla vurup surlardan düşürdüler ve bazılarını da ateşe atarak eziyet ettiler. Sokaklarda kesik kafalardan, ellerden ve ayaklardan yığınlar oluştu. Yürürken insan ve at cesetlerinin üzerinden geçmeniz gerekiyordu.

Bebekler annelerinden alınıp kafaları duvarlara vurularak ezildi. Bu vahşet sürerken 'Müslümanlar, Araplar ve Habeşliler -Fatımi ordusundaki siyahi askerleri kastediyordu- Kubbetüs Sahra ve el Aksa'nın damına sığındılar. Ama şövalyeler Kubbetü's-sahra'ya doğru giderlerken kalabalık avluyu ortada yararak kendilerine yol açıp 'Tapınak'ta (Süleyman Tapınağı, Haçılır el Aksa'ya öyle diyordu) kan, atlarının dizginlerine yükselene dek öldürmeye devam ettiler. Böylece bu mekânın kâfirlerin kanıyla dolmasını dileyen Tanrı'nın adil ve müthiş hükmü yerine getirilmiş oldu.

Aralarında pek çok Müslüman din adamı ve Sufi sofunun da olduğu on bin Müslüman, Tapınak Dağı'nda öldürüldü, bunlara el Aksa'da öldürülen üç bin kişi de dâhildi. Vakanüvis Chartreli Fulcher, 'Cladyatörlerimiz el Aksa'nın üzerindeki Müslümanları okla vurmaya başladılar. Daha ne anlatayım? Ne çocuk ne kadın hiç biri 
sağ bırakılmadı,' diye yazmıştı. Fakat Tancred, el Aksa'nın çatısında kalan son üç yüz kişiye, korunduklarını gösteren, sancağını gönderdi. Katliamı durdurdu, bazı değerli esirleri alıp onlardan Tapınak Dağı'ndaki hazineleri göstermelerini istedi. Daha sonra oradaki sunaklardaki asılı olan büyük altın fenerleri yağmaladı. Yahudiler sinagoglarına sığındı ama Haçılıar sinagoglarını ateşe verdi. Yahudiler, sanki İsa'nın adına adanan kurbanlar gibi, diri diri yakıldılar. Boullionlu Godfrey kılıını çıkardı ve maiyetiyle birlikte şehirde dolaşıp dua etti ve daha sonra Kutsal Kabir'e gitti.

Ertesi sabah, Tancred'i hiçe sayan Raynond'un askerleri el Aksa'nın çatısına tırmandı ve orada bekleşen erkek ve kadınların tümünün kafasını kesti. Bazı Müslümanlar kendini aşağı attı. İran, Şiraz'dan gelmiş olan sayggdeğer bir kadın âlim diğer kadınlarla birlikte Kubbetüs Silsile'ye sığınmıştı. Onları da öldürdüler. Kurbanların uzuvlarını kesmekten, sanki ibadet eder gibi, farklı bir haz alıyorlardı. 'Her yer insan cesetleri, kesik başlar ve uzuvlarla kaplıydı.' Gözünü kan bürümüş, tepeden tırnağa kana bulanmış ve gören herkesin kanını donduran Haçılırın görüntüleri ise bu manzaradan bile daha dehşet vericiydi. Her tarafı arayıp bulduklarını 'koyun gibi doğramaya' devam ettiler.

Her Haçlıya kendi silahı ve kalkanıyla işaretlediği eve sahip olma sözü verildi: ‘Bu yüzden hacılar şehri dikkatle aradılar ve şehir sakinlerini, kadınlar ve çocuklarla birlikte tüm aileleri öldürdüler, girdikleri evlerde yaşayanların çoğunu yüksek pencerelerden aşağı attılar.'

Ayın 17'sinde hacılar (caniler kendilerine böyle diyorlardı) nihayet öldürmekten bıktılar ve 'dinlenip yemek yiyerek kendilerini toparladılar. Prens ve rahipler Kutsal Kabir Kilisesi'ne gidip ilahiler söylediler, neşeyle el çırptılar, sunakları sevinç gözyaşlarıyla yıkadılar ve daha sonra Tanrı'nın Tapınağı (Kubbetüs Sahra) ile Süleyman Tapınağı'na gittiler. Sokakları örten ceset parçaları yaz sıcağıyla kokmaya başladı. Prensler hayatta kalan Yahudi ve Müslümanlara bu parçaları toplatıp büyük ateşlerde yaktırdılar, daha sonra onları da muhtemelen kendi yaktıkları ateşe atarak öldürdüler (Montefiore, 2016: 215-217).

Belirleyici misyonu Haçlıların yaptıklarını değerli bir miras olarak gelecek nesillere aktarmak olan Willermus bir din adamıdır. Sur başpiskoposluğu görevinin yanı sıra Haçlı Kudüs krallığına elçilik yapmış ve Haçlı Kudüs Kralı Amaury'ın oğlu Balduin'in eğitmenliğini üstlenmiştir. Oldukça hacimli kroniğini Kudüs Haçlı kralının isteği doğrultusunda kaleme almıştır. Willermus ilmi derinliğine, farklı kişiliğine ve görece diğer kronik yazarlarına göre Müslümanları daha yakından tanımasına rağmen, dindaşları olan Hıristiyan Haçlıların yaptıklarını haklı görüp meşrulaştırıyor. Daha ötesi yapılanların Tanrı'nın adaleti olduğunu iddia ediyor: "Bu, batıl inançlarıyla Rabb'in kutsalını kirletenlerin ve müminleri mahrum bırakanların günahlarının kefaretini ölümleri ve kanlarıyla temizlemeleri için, Tanrı'nın adaleti idi"(Willermus, 2016: 1/363).

Willermus, Haçılıarın Kudüs'ü işgal ederken yaptıkları vahşet ile ilgili şunları aktarıyor:

“XIX. Dük ve yanındakiler derhal kınından çekilmiş kıııcları, kalkanları ve miğferleriyle mücehhez olarak sokaklara ve şehrin meydanlarına giderek, yaş ve cinsiyete bakmaksızın buldukları bütün düşmanları kılıçtan geçirdiler. Her tarafta o kadar çok insan kellesi yığıldı ki, cesetlerin üzerinden başka geçecek yol kalmadı. Ve prensler çok sayıda halkla beraber, kâfirlerin kanını döktükçe daha da susayan bu caniler olmadan, çeşitli yollardan neredeyse şehrin merkezine gelirken, Toulouse Kontu ve onun 
yanında bulunan diğer prensler hala Sion Dağı üzerinde savaşıyorlar ve şehrin zapt edildiğini ve haçılıarın eline geçtiğini bilmiyorlardı. Burada direnen halk, Haçııların şehre girmesi ve galibiyet kazanması üzerine nihayet müthiş bir gürültü ve feryat kopardı. Bunun üzerine bu sıra dışı gürültü ve kargaşanın ne anlama geldiği merakla sorulunca, Haçlı ordusunun şehirde olduğu anlaşıldı ve bunlar burçları ve surları bırakıp, hayatlarını kurtarmak için çeşitli yerlere kaçtılar. Bunlardan ekserisi komşu kaleye kaçtılar ve ordunun kolayca surlara dayanabildiği köprüye girip, merdivenler yardımıyla hiçbir mukavemet görmeden, yarışırcasına şehre girdi. Şehre girince, kendilerine en yakın olan güney tarafındaki kapıyı açarak, böylelikle halkın zorlukla karşılaşmadan şehre girmesini sağladılar. Böylece cesur ve şanlı adam Toulouse Kontu, Kont Isoard von Die, Raimund Pelet, Wilhelm von Sabran, Albara Piskoposu ve sayıları ve adları verilmemiş olan daha pek çok soylu şehre girdiler. Bunlar dişlerine kadar silahlı ve tamamen zırhlı olarak hep birlikte şehre girdiler ve çok müthiş bir katliam gerçekleştirdiler. Dükten ve adamlarından kaçıp, hayatlarının kurtarmış olduklarını zannedenler, şehrin diğer tarafına yöneldiklerinde, şimdi bunların ellerine düştüler ve kharybdis'in girdabından kurtulup Skylla'ya yakalandılar. Böylece şehirde o kadar çok insan öldürülüp, o kadar çok kan döküldü ki, galiplerin kendileri bile dehşete düştüler.

$X X$. Halkın büyük bir bölümü tapınağın salonuna kaçtı, çünkü burası şehrin uzak bir kısmında olup, bir duvar, burçlar ve kuvvetli kapılarla tahkim edilmişti. Fakat bu kaçış onları kurtaramadı çünkü Tankerd ordunun çok büyük bir kısmıyla oraya gitti. Cebren tapınağa girip, sayısız insanı katletti. $\mathrm{O}$, ayrıca sayısız miktarda altın, gümüş, mücevher ele geçirip, ilk kargaşa yatıştıktan sonra bunları eski yerlerine bıraktı. Şehrin öbür kısımlarını ele geçirdikten ve katliam yaptıktan sonra diğer prensler de tapınağa gittiler, onların arkasından kaçan ahali de gizlendi. Bunlar bir miktar atlı ve piyadelerle içeri girip, ayırt etmeksizin kime rastladılarsa kılıçtan geçirdiler ve her tarafı kan doldurdular. Bu, batıl inançlarıyla Rabb'in kutsalını kirletenlerin ve müminleri mahrum bırakanların günahlarının kefaretini ölümleri ve kanlarıyla temizlemeleri için, Tanrı'nın adaleti idi. Her yerde yatan cesetlere ve kanla örtülen insan uzuvlarına bakmak korkunçtu. Ve sadece parçalanmış cesetler ve kesilmiş kafalar kötü bir manzara teşkil etmiyor, baştan ayağa kana bulanmış galiplerin görüntüsü de ürpertiyordu. Tapınağın etrafından on bin Müslüman katledilmiş olmalıdır, şehrin orasında burasında öldürülüp, sokaklarda, meydanlarda bulunan cesetler hesaba katılmamıştır, çünkü bunların sayısı da daha az değildir. Ordu şehirde dağıldı ve dar sokaklarda gizlenmiş olanları bulup, sığır gibi kestiler. Diğerleri birleşip evlere girip, ana, baba, çocuk ne varsa dışarı çıkarıp ya kılıçlarla öldürdüler ya da çatılardan aşağı atıp boyunlarını kırdılar. Girdikleri evleri mülk edindiler, çünkü şehir zapt edildikten sonra ele geçirdiklerini yasal mülkiyet edinme hususunda birbirleriyle anlaşmışlardı. Böylece kente girip, halkın evlerini ve gizli sığınaklarını ele geçirdikten sonra, herhangi birisi geldiğinde burasının bir sahibi olduğunu anlasın ve yoluna devam etsin diye kapıya bir kalkan veyahut herhangi bir silah asıyordu" (Willermus, 2016: 1/ 361-364).

Dikkatlerden kaçmayan önemli bir husus, Müslüman tarihçilerin, Batılı kronikçiler kadar Kudüs'te yaşanan korkunç katliamı detaylandırmamalarıdır. Batılı kronikçilerin böyle detaylı anlatmalarının en önemli sebebi, bir kısmının bu vahşetin bizzat failleri olup ona tanık olmaları ve bunu bir misyon olarak gelecek nesillere aktarmak istemeleridir. Anlatmalarında mahcubiyet, pişmanlık, iğrenme, hayıflanma, yakıştıramama yok. Aksine yapılanları meşru ve doğru görerek ve tasvip ederek anlatıyorlar. Daha da ötesi, yapılanların Tanrılarının adaleti, istek ve 
arzusu doğrultusunda yapıldığını ve bunu yapanları da bu arzuyu gerçekleştiren kahramanlar olarak gösteriyorlar.

Müslüman tarihçiler ise genellikle olayları detaylandırmadan sade bir üslupla anlatmayı yeğliyorlar. Anlatımlarında propaganda ve ajitasyon amaçı bir anlatı hissedilmiyor. Kudüs'te yaşananların detaylı bir şekilde aktarılmamasının sebebi, belki de Kudüs'te katliamdan sonra olayları Müslümanlara aktaracak hiçbir Müslüman şahidin geride kalmamasıdır.

İbnü'l-Esir, yaşananları kısaca anlattıktan sonra yetmiş binden fazla Müslümanın öldürüldüğünü belirtiyor. Haçlıların başarısını da Müslüman Sultanların birbirine düşmeleri sebebiyle olduğunu söylüyor (İbnü'l-Esir, 1987: 10/236). ilginç olan ise hem o dönemin hem de Şam tarihi hakkında kitap yazan Kalanisi'nin yaşanan katliam hakkında neredeyse hiçbir şey yazmamış olmasıdır: "Frenkler Beytülmakdis'e hücum ederek ele geçirdiklerinde ahalinin bir kısmı Mihrab'a sığındı. Bu yılın Şaban ayının 22'sinde Mecid-i Aksa eman ile teslim edildi. (Temmuz 1099) Frenkler şehitlikleri ve Halil ibrahim (as) kabrini yıktılar"(Kalanisi, 2016: 61). Kalanisi'nin anlattıkları bundan ibaret. Kalanisi'nin yaşananları duymamış olması mümkün değildir. Doğrusu bu şaşırtıcı bir durumdur.

İbnü'l-Kesir, Hicri 492. Senesiyle ilgili anlattığı olayların başında Frenk/Haçlıların Kudüs'ü zapt etmelerinden bahsediyor. 60 ooo'den fazla Müslüman öldürülmüş ve Kudüs'ün zenginliklerini ele geçirmişler. Müslümanların nasıl katledildikleriyle ilgili detaylı bilgi yok. Müslümanların çaresizliğinden ve cihad hususundaki isteksizliklerini vurguluyor. Aktardığı şiirler ise Haçlıların Müslümanları nasıl katlettikleri konu ediyor. Buna karşılık Müslümanların acziyeti vurgulanıyor (İbnü'l-Kesir, c. 12, s. Hicri 492 sene olayları).

\section{Selahaddin'in Kudüs'ü Fethi}

Haçlılar, ne Müslüman ne de Yahudi, Kudüs'e tek bir kişiyi sağ bırakmamışlardır. Onlar yaptıkları katliamdan sonra, tarihte belki de eşi görülmemiş vahşette katliamlarını ve işgallerini şükran ve sevinç gösterileriyle kutlamışlardır (Carnotensis, 2009: 106). Sevinç içinde olan Batı âlemi için Kudüs'ün ele geçirilmesi mucizevi bir başarıydı. Papa II. Urbanus ise Kudüs'ün ele geçirilmesi haberi Roma'ya ulaşmadan birkaç gün önce ölmüş olduğundan, bu sevinci dindaşlarıyla paylaşamamıştı (Demirkent, 1997: 56). Malouf'un ifadesiyle Haçlıların Kudüs'ü yağmalaması ve yaptıkları katliam, İslam âlemi ile Batı arasında bin yıllık bir husumetin başlangıç noktasını meydana getirmiştir(Malouf, 1998: 15).

Haçlılar, tam seksen sekiz sene Kudüs'ü işgal etmeye devam etmişlerdir. Kudüs'ün ilelebet ellerinde kalacaklarına inanmışladır fakat Selahaddin Eyyubi, yanıldıklarını onlara 1187 tarihinde, Hıttin'de birleşik Haçlı ordusunu, tarihlerinde benzeri olmayan bir hezimetle mağlup ettikten sora göstermiștir. ${ }^{4}$ Böylece Kudüs, muzaffer kumandan Selahaddin'in komutasında 88 yıllık işgalden kurtulmuş ve asıl kimliğine yaraşır bir şekilde imar edilerek selamet yurdu haline getirilmiştir. 
Müslüman Selahaddin, Haçlılara sadece yanıldıklarını göstermemiştir. O, Kudüs'ü fethederken hem Haçlılara hem de bütün dünyaya Haçlılardan tamamen farklı olduğunu göstermiştir. O, kimin adil, kimin zalim olduğunu; kimin merhametli kimin gaddar olduğunu, kimin barbar, kimin asalet sahibi olduğunu, kimin insani erdemlere sahip, kimin insanlıktan çıkmış canavarlar olduğunu ve kimin kurtarıcı kimin ise işgalci olduğunu göstermiştir. Dost-düşman, Hıristiyan yahut Müslüman fark etmeksizin insaf ve vicdan sahibi her bir insan bu farklılığa şahitlik etmektedir. Kudüs'ün her bir taşı da buna şahitlik etmektedir.

Müslüman Selahaddin, Kudüs'ü fethederken seksen sekiz sene önce Haçlıların yaptığını yapmamıştır; aksine mağluplara merhamet ve adaletle davranmıştır. Öyle ki Selahaddin bu davranışlarıyla düşmanlarından dahi övgü, takdir, şükran, minnettarlık görürken, Haçlılar yaptıkları hunharlık, şiddet ve katliamlarla yandaşlarından dahi bazılarının iğrenmesine sebep olmuştu.

\begin{abstract}
“2 Ekim Cuma günü Selahaddin Kudüs'e girdi; bu, Hz. Peygamber'in Mescidülaksa'dan urüc ettiği 27 Receb [Mi'rac Kandili] günüydü. Haçlıların 88 yıl önce Müslümanların kanılla suladıkları şehirde ne bir insana dokunuldu, ne de bir bina yağma edildi. Hiçbir taşkınlık yapılmadı. Müslümanlar zaferlerinin sevincini olgunluk içinde sükûnetle kutlamaktaydılar. Kudüs'den giden mülteciler Sur, Trablus ve Antakya'ya sığınırken, Ortodokslar ve Yakubiler Kudüs'te kaldılar. Musevilerin de şehre yerleşmesine izin verildi. Hristiyanlara ait kutsal yerlerin idaresi Ortodoks kiliseye teslim edildi” Demirkent, 1997: 141).
\end{abstract}

Bir Haçlı olan kronik yazarı Ernoul, Selahaddin'in Kudüs'ü nasıl fethettiğiyle ilgili konuya genişçe yer vermektedir: Kudüs'ün nasıl düştüğünü, Balian ile Selahaddin arasında anlaşmanın sağlanması için görüşmelerin nasıl başlandığı ve nasıl bir sonuca vardıkları vs. Biz konumuzla ilgili olarak yazdıklarından sadece bazı bölümlerini aktarmakla yetineceğiz:

\footnotetext{
"Şimdi de size Müslümanların şehirdeki Hıristiyanlara zarar vermesinler, fenalık etmesinler, saldırmasınlar diye Selahaddin'in Kudüs şehrinde asayişi nasıl sağladığını anlatacağım. Nöbetçi olarak her kapıya ve her sokağa 2 şövalye ve 10 asker koydu. Bunlar kendilerine verilen vazifeyi o kadar iyi yerine getirdiler ki Hıristiyanlara fenalık edildiğine dair hiçbir şikâyet işitilmedi.

Hıristiyanlar Kudüs'ten çıktıkça Müslüman ordusunun önüne yerleşiyorlardı. Bir ordudan ötekine doğru tek bir yay gerilip, tek bir ok bile atılmadı. Hepsi çıkıncaya dek orada toplandılar. Selahaddin Hıristiyanların ordusunu onlara zarar verilmemesi ve hırsızların soygun yapmaması için gece gündüz muhafaza altında tuttu.

Fidyelerini karşılayabilenlerin ve kurtulmalıkları ödenen yoksulların tamamı Kudüs'ten çıktıktan sonra içeride hala çok sayıda yoksul kalmıştı. Bunun üzerine kardeşi el Adil Selahaddin'e gitti ve Efendimiz, Allah'ın izniyle bu toprakları ve bu şehri fethetmene yardımcı oldum, lütfedin de bana şehirde kalan bu yoksullar arasından bin köle ihsan eyleyin," dedi. Selahaddin onun dileğini yerine getirilmesini emretti ve esirler getirilirdi. Selahaddin hizmetkârlarına bin köleyi ayırmalarını buyurdu. Selahaddin'in buyruğunu işitince derhal yerine getirdiler. El Adil bin köleyi alınca, onları Allah rızası için azat etti.

Bunu gören patrik şehirde kalan ve fidyesini ödeyemeyen yoksullardan kendisine verirse duacı olacağını söyledi. Sultan ona da 500 yoksul esir ihsan etti, patrik bu kişileri azat etti. Onu takiben Balian d'Ibelin, Selahaddin'in huzuruna geldi ve o da
} 
yoksular arasından birilerinin kendisine bağışlanmasını diledi. Buna mukabil ona 500 yoksul esir bağışlandı, Balian bu kişileri azat etti. Bunun üzerine Selahaddin adamlarına dönerek, "kardeşim sadaka verdi, Balian ve patrik de onu takip etti, şimdi de ben bunun mislini yapmak isterim," dedi. Ve Kudüs'teki hizmetkârlarına Aziz Ladre yaya kapısını açmalarını emretti. Davud Kapısı'na asker koydurdu ve bütün Kudüs'te tellallara şehirdeki yoksulların gün doğumu ile gün batımı arasında kentten çıkabileceği haberini duyurdu. Ve askerlerine kapıdan çıkan herkesi aratmalarını, üzerlerinden fidyesini ödeyebilecek mal veya para çıkanları yakalayıp zindana atmalarını emretti. Yaşlıları şehir dışına çıkarırlarken tedbiren genç oğlanları ve kızları iki sur arasına aldılar. Bu aramalar ve yoksul kişilerin surların dışına çıkarılması güneşin doğuşundan batışına dek sürdü. Ve Aziz Ladre Kapısı'ndan dışarı çıkardılar. Selahaddin böylece sayısız yoksulu sadaka olarak azat etti.

Daha sonra şehirde kalanlar hesap edildi, 11 bin kişi kaldığı görüldü. Patrik ve Balian hala fidyesi ödenmemiş 11 bin kişi kaldığını görünce Selahaddin'e geldiler; ona tanrı aşkına yalvararak, kendilerini rehine alması karşıında yoksulları serbest bırakmasını, Hıristiyan âleminden fidye parasını toplatacaklarını, böylece fidyeyi ödeyeceklerini söylediler. Selahaddin onlara artık yapacak başka bir şey olmadığını, 11 bin kişiye karşııık 2 adamı rehin alamayacağını, artık bundan bahsetmemelerini söyledi. Bu emre riayet ettiler ve kalanlar esir oldu.

Şimdi de Selahaddin'in kocaları muharebede ölen veya esir düşen şövalyelerin Kudüs'teki hanımlarına ve kızlarına karşı gösterdiği hürmetten bahsedeceğim. Hanımlar, fidyeleri ödenip Kudüs'ten çıkarılırlarken bir araya geldiler ve Selahaddin'in huzuruna çıkarak merhamet dilediler. Selahaddin onları görünce kim olduklarını ve ne istediklerini sordu. Kadınlar, muharebede ölen ve esir düşen şövalyelerin hanımları ve kızları olduklarını söylediler. Bunun üzerine onlara ne arzu ettiklerini sordu. Kadınlar Tanrı'dan kendilerine merhamet etmesini dileyerek, kimisinin kocasının zindanda olduğunu, kimisininkinin öldüğünü, topraklarını kaybettiklerini söylediler ve Tanrı aşkına kendilerine yardım etmesini istediler. Selahaddin onların ağladıkların görünce içini büyük bir merhamet kapladı, o da acıma duygusuyla gözyaşı döktü. Kocaları hayatta olan hanımlara, kocalarının hangi zindanda olduğunu söylemelerini buyurdu. Çünkü esir olanları serbest bıraktıracaktı. Dediği gibi orada bulabildiklerinin hepsini azat etti. Daha sonra babaları ve kocaları muharebede ölen hanımlara ve genç kızlara kendi hazinesinden, mertebesine göre, kimine daha az kinime daha çok bağıșta bulundu. Selahaddin onlara iyiliğinin ve şerefinin nişanesi olarak, itibarlarına göre dağıtılmak üzere bolca ihsan ve bağış eyledi”(Ernoul, 2009: 178-180)5.

"Şimdi de size Selahaddin'in Kudüs'ü zapt ettikten ve Tapınakçıların önderliğinde ilk kafileyi gönderdikten sonra ne yaptığını anlatacağım. Sultan tüm Hıristiyanlar şehirden çıkııtan sonra Tapınağa gitmenden ve Tapınakta dua etmeden şehirden ayrılmak istemedi. Daha önceden Hıristiyanların elinde olduğu için Tapınağa girmeden önce Dımaşk'a haber gönderip 4 veya 5 deve üzerinde Tapınağı yıkamaya yetecek kadar gül suyu getirtti. Gül suyu gelince Tapınağın içini bu gül suyuyla yıkattı. iç̧eri girmeden evvel tapınağın tepesine dikilen altından dev haçı yerinden söktürdü. Müslümanlar yere düşen haçı aldılar ve ip bağlayıp Davud Kulesi'ne dek yerde sürüklediler. Müslümanlar haçı orada parçaladılar ve sürüklenirken arkasından bağırıp çağırdılar. Size bunun Selahaddin'in emriyle yapılmadığını, hadisenin kendiliğinden geliştiğini söyleyebilirim.

Tapınaktaki haç çıkarılınca Selahaddin Tapınağı yıkattı ve içine girdi. Allah’a dua etti ve hanesine beylik nasip ettiği için şükretti” (Ernoul, 2009: 183).

Poole, Selahaddin ve Hıristiyan papazı mukayesesini yapmaktadır. Bir yandan ahlakı ve vicdanı olmayan açgözlü Hıristiyan papaz, diğer yandan sözünde duran 
hayırseverliğin manasını Hıristiyan papaza öğreten erdem sahibi Müslüman Selahaddin:

\begin{abstract}
"Ne ahlakı, ne de vicdanı olmayan patrik kiliselerin hazinelerini, altın kadehleri ve vitrinleri ve hatta kutsal kabrin altın tabaklarını alıp götürdü, ayrıca onun büyük definesi hala kalan yoksulların fidyesini ödemeye harcanabilirdi. Sarazen emirler Selahaddin'e yaşlı alçağın ganimetiyle kaçmasına izin vermemesi için baskı yaptığında, o, 'Hayır, ondan desteğimi çekmeyeceğim,' diye yanıtladı ve patrik on Bizans sikkesi için geriye kalanlar gibi gitti. ${ }^{6}$ Hristiyan papaza hayırseverliğin anlamını öğretmek Müslüman hükümdara kaldı" (Poole, 2012: 211-212).
\end{abstract}

Selahaddin, patrikten götürdüklerini alsaydı, muhtemelen kimse onu kınamazdı. Belki de açgözlü Patriğe haddinin bildirilmesi olarak değerlendirilirdi. Fakat buna rağmen Selahaddin mala tamah göstermeyip erdemi tercih etti. Selahaddin bu tercihte bulunurken, Haçlılar, 1099 yılında Kudüs'ü ele geçirirlerken, Müslümanların paraları yutmuş olabileceği paralarını ele geçirmek için ya ölmüş Müslümanların karınlarını deşiyorlardı ya da onları toplu halde yakıyorlardı.

İşte Hıristiyan Haçlıların ve Müslüman Selahaddin'in arasındaki kıyaslanmayan zihniyet farkı tam da burada kendisini gösteriyor. Daha öte söze gerek var mı?

Acıma ve acımasızlık, merhamet ve merhametsizlik; iki farklı zıt kutup, iki karşıt zihniyet ve eylem. Selahaddin ve Müslümanlar düşmüş şehre merhamet gösterirken, merhametle özleştiklerini iddia eden Hıristiyan Haçılar acımasızlıkta sınır tanımamışlardı. -Hâlbuki Hz. İsa'nın öğretisinin temeli merhamete dayanıyordu- Poole, bu farklılığın ve zıtlığın mukayesesine vurgu yapıyor:-

\footnotetext{
"Böylece Sarezenler düşmüş şehre merhamet gösterdiler. Godfrey ile Tancred öldürme ve ölülerle tıka basa doldurulmuş sokaklar boyunca atlarını sürdüğünde, korunmasız Müslümanlara kuleler ve Tapınağın çatısı üstünde soğukkanlılıkla işkence edildiği, yakıldığı ve silahla vurulup öldürüldüğünde, kontrolsüz katliamın kanı Hıristiyanlık onurunu kirlettiğinde ve bir zamanlar sevginin gerçeğinin ve acımanın vaaz verildiği sahne kirlendiğinde, birisi Haçılırın 1099'daki acımasız zaferini anımsar. Hıristiyanlar kutsal şehirden ayaklarını sürüyerek yürürlerken, 'kutsanmıştır bağışlayııılar, çünkü acıma süregelecek,' unutulmuş bir şiardı. Şanslıydı merhametsizler, çünkü onlar Müslüman sultanın elinde merhamet bulmuşlardı.

'Cennetin en büyük niteliği merhamettir

Ve $o$ adalet ve ihtişamın tacıdır

Doğrulukla öldürebileceği yerde, acımayla kurtarmak için" (Poole, 2012: 211-212).
}

Selahaddin'in en büyük arzusu ve hedefi Kudüs'ü işgalci Haçlıların elinden kurtarıp tekrar bir Müslüman kenti yapmaktı. Bunun için çok çabaladı ve arzusunun önündeki küçük büyük tüm engelleri tek tek aştı. Hittin savaşında birleşik Haçlı ordusunu hezimete uğratarak hedefine çok yaklaştı. Aynı yıl içinde Kudüs'ün surların arkasındaki Haçlı savunmasını da aşarak nihayet büyük arzusuna ve hedefine ulaştı. Geride 88 yıllık işgalinin izlerini tamamen silip şehri kutsiyetine ve şanına yaraşır bir anlayışla korumak, geliştirmek ve mamur hale getirmek kalmıştı. Bunun için hiç vakit kaybetmeden tadilat, restorasyon ve imar 
faaliyetlerine başladı. O asrın Müslüman şahitlerinden olan büyüt tarihçi İbnü’lEsir şunları kaydetmektedir:

"Selahaddin şehre girip kâfirler şehri terk edince, binaların eski haline iade edilmesini istedi. Templier tarikatı mensupları Mescid-i Aksa'nın batısında oturmak için meskenler yapmışlardı. Ayrıca depolar, dinlenme yerleri vs. de inşa etmişler, Mescid-i Aksa'nın bir kısmını da kendi binalarına dâhil etmişlerdi. Bunlar da eski şekline iade edildi. Selahaddin Mesid-i Aksa ve Kubbetu's-Sahra'nın her türlü pislik ve süprüntüden temizlenmesini emretti, bu emir de yerine getirildi.

Ertesi hafta Cuma günü 4 Şaban (9 Ekim 1187) tarihinde Müslümanlar Mescid-i Aksa'da Cuma namazı kıldılar, Selahaddin de onlarla beraberdi. Kubbetu's-Sahra'da da namaz kıldılar. Cuma namazında Dımaşk kadısı Muhyiddin b. Ez-Zeki imamlık ve hatiplik yaptı, daha sonra Selahaddin bir menşur ile beş vakit namaz kıldırmak üzere bir imam ve hatip tayin etti ve Mescid-i Aksa'ya bir minber yapılmasını emretti. Bunun üzerine ona Nureddin Mahmud'un Haleb'de bir minber yaptırdığını, sanatkârına minberi çok güzel ve sağlam bir şekilde yapmasını emrettiğini ve: 'Biz bunu Kudüs'e konulmak üzere yaptırdık.' Dediğini anlattılar. Marangozlar bu minberi senelerce uğraşıp yapmışladır ve İslam âleminde benzeri yoktu. Selahaddin bu minberin getirilmesini emretti, bunun üzerine minber Haleb'den Kudüs'e getirildi. Minberin yapılmasıyla Kudüs'e nakli arasında yirmi yıldan fazla zaman geçmişti ki bu Nureddin'in kerametlerinden ve güzel gayelerinden birini teşkil eder. Allah rahmet eylesin.

Selahaddin Cuma namazını kıldıktan sonra Mescid-i Aksa'nın tamir edilmesini, sağlam ve mükemmel bir surette yapılması ve nakışlarına özen gösterilmesi için bütün imkânların seferber edilmesini emretti; bunun üzerine benzersiz güzellikle mermerler, Kostantıniyye yapımı altın yaldızlı siyah taşlar ve ihtiyaç duyulan diğer şeyleri getirdiler. Bunlar yıllar boyu biriktirilmişti. Hemen tamirata girişilirdi. Binalardaki resimleri yok ettiler. Frenkler Sahra'nın üzerine mermer döşeyerek onu gözden kaybetmişlerdi. Selahaddin bunun açığa çıkarılmasını emretti” (ibnü’l-Esir, 1987: 11/ 435-436; Şeşen, 2013: 102).

Haçlılar, Kudüs'ü ele geçirirlerken Müslüman ve Yahudilerin tamamına yakınını katlettiler. Şehir tamamen Müslüman ve Yahudilerden boşaltıldı. Selahaddin, Avrupa'dan gelen işgalci Frenk/Haçlı ile Kudüs'teki doğulu Hıristiyan ayrımını yapıyordu. İşgalci Frenklerin Kudüs'te kalmalarına izin vermezken, doğulu Hıristiyanları kendi vatandaşları olarak kabul edip cizyelerini vermeleri halinde şehirde kalmalarına izin vermiştir. (Ibnü'l-Esir, 1987: 11/ 436; Şeşen, 2013: 102; Jackson, 2016: 335).

Fetihten sonra Mescidü'l-aksa'da ilk hutbeyi okuma şerefine nail olan Muhiddin ibn el-Zeki siyah hilatle minbere çıkmış ve tarihi konuşmayı yapmıştır:

“islam'a bu zaferi veren ve onu bir yüzyıllık bir yoldan çıkıştan sonra hak yoluna döndüren Allah'a hamd olsun. Fethi gerçekleştirmek için seçtiği bu orduya şan olsun. Ve bu ulusa alay edilen saygınlığını veren Eyüp oğlu Selahaddin Yusuf, Allah'ın selamı senin üzerine olsun" (Malouf, 1997: 261).

Poole, Selahaddin'in Kudüs'ü fethi ile ilgili şu anlamlı değerlendirmede bulunuyor: 
“Eğer Kudüs'ün fethi Selahaddin hakkında tek bilinen gerçekse, bu onun kendi çağının ve belki de her çağın en cömert ve cesur fatihi olduğunu kanıtlamaya yeterdi” (Poole, 2012: 212).

\section{SONUÇ}

Kudüs, özel ve özne bir şehirdir. O, hem kutsal hem de kıblegahtır. İnsanlığa Tevhide dayalı bir inanç ve zihniyetle istikamet gösterir. Bu istikamette Ibrahim (as)'in gösterdiği sirat-i müstakim vardır. Bu sırat-i müstakim, tevhid, adalet ve merhamet yoludur. İstikametin sembolü olan Mescid-i Aksa; Zebur okuyan, hükümdarlık, hikmet ve ilim sahibi, Peygamber-hükümdar Davut (as) tarafından temeli atılmıştır. Ondan sonraki peygamberler de aynı istikamet üzere insanları tevhid, adalet ve merhamete davet etmişlerdir.

Tarihin değişik dönemlerinde Kudüs'ün istikametini bozmak isteyenler olmuştur. Putperest Romalılar gibi açıkça batıl adına istikametini bozmak isteyenler ile Haçlı Hıristiyanlar gibi gerçekte hak olmadığı halde hak iddiasıyla istikametini bozmak isteyenler. Fakat her defasında bunlara hadlerini bildirenler de olmuştur. Aynı akıbet Siyonist işgalci İsrail devletini de beklemektedir.

Bu çalışmada Kudüs'ün şahitliğini esas alarak iki farklı ve zıt anlayışın mukayesesini yapmaya çalıştık. Bu iki zıt anlayış hak ve batıl anlayışlarıdır. Hak tarafı, adalet, merhamet ve ıslahı temsil ederken, batıl tarafı ise sapkınlık, adaletsizlik, merhametsizlik, ifsad ve işgali temsil etmektedir. Davut (as), Süleyman (as), İsa (as), Hz. Ömer ve Selahaddin hakkın tarafındayken, Calut, Nebukadnezzar, Titus, Haçlılar ve Siyonistler ise batıl tarafındadır. Kudüs, bir dünya şehridir. Asıl sahipleri ise Filistinlilerdir, Siyonistler değil.

Kudüs, Yahudilik, Hıristiyanlık ve İslam için kutsal bir şehirdir. Bu özelliğinden dolayı üç dinin de temsiliyeti olmalıdır. Bu üç dinin mensupları ismine, kimliğine ve misyonuna yaraşır bir şekilde Kudüs'ü insanlığa örnek bir barış ve huzur yurdu haline getirme ideal ve iddiasına sahip olmalı ve bunun için çaba göstermelidirler.

\section{KAYNAKÇA}

Carnotensis, Fulcherius. (2009). Kudüs Seferi-Kutsal Toprakları Kurtarmak-(Gesta Francorum Jherusalem Peregrinantium). İcan Bihter Barlas (Çev.). İstanbul: IQ Kültür Sanat Yayıncilık.

Demirkent, Işın. (1997). Haçlı Seferleri. İstanbul: Dünya Yayınları.

Ernoul, (2019). Haçlı Seferleri Tarihi Selahaddin Eyyubi ve Kudüs'ün Fethi. Ahmet Deniz Altunbaş (Çev.). İstanbul: Kronik kitap Yayınları.

Gül, Muammer. (2001). Kudüs ve Tarih İçinde Aldığı İsimler. Web. Fırat. Edu.tr adresinden alındı.

Harman, Ömer Faruk. (2002). Kudüs. Ankara.TDV İslam Ansiklopedisi. C. 26. S. 323-227.

İbni Şeddat, Kadı Bahaeddin. (2001). Siretü Selahaddin el-Eyyubi. Halep: Darü'l-Kalemü’lArabiyye yayınları.

İbni Kalanisi. (2016), Ibn Kalanisi Hayatı ve Eserleri "Zeylü tarihi Dımaşk" Tercemesi. Hasan Aydın (Çev.). İstanbul: Marmara Üniversitesi Türkiyat Araştırmaları Enstitüsü Türk Tarihi Anabilim Dalı Ortaçağ Tarihi Bilim Dalı Yüksek Lisans Tezi. 
İbnü'l-Esir. (1958). Al-Kamil Fittarih Tercümesi. Abdulkerim Özaydın (Çev.). İstanbul: Bahar Yayınları.

İbnü’l-Kesir. (1996). El-Bidaye-Ve'n-Nihaye: Büyük İslam Tarihi. Mehmet Keskin (Çev.). İstanbul: Çağrı Yayınları.

Lyons, Malcolm Cameron- Jackson, D.E.P. (2006). Selahaddin Kutsal Savaşın Politikaları. Zehra Savan (Çev.). İstanbul: Pınar Yayınları.

Malouf, Amin. (1998). Arapların Gözüyle Haçlı Seferleri. İstanbul: Telos.

Montefiore, Sımon Sebag. (2016). Kudüs Bir Şehrin Biyografisi (Jerusalem The Biography). Cem Demirkan (Çev.). İstanbul: Pegasus Yayınları.

Mustafa, Şakir. (2014). Selahaddin. Dımaşk: Darü'l-Kalem.

Polat, Ziya. (2019). "Fulcherius Carnotensisi'te İslam ve Müslüman algısı”. Turkish Studies, International Balkan University, Skopje/Macedonia-Ankara/Turkey, 413-632. Doi: 10.7827/Turkish Studies. 14924.

Poole-Lane, Stanley. (2012). Selahaddin. Nice Damar (Çev.). İstanbul: Avesta Yayınları.

Runciman, Steven. (1990). A History of the Crusades, New York: Cambridge University Press.

Sallahbi. Ali Muhammed. (2006). Eyyubi Devleti Salah ad-Din Eyyubi ve Kudüs'ün Yeniden Fetih. İstanbul: Ravza Yayınları.

Şeşen, Ramazan. (2013). Kudüs Fatihi Salah ad-Din Eyyubi. İstanbul: Yeditepe Yayınları.

Taberi. (1991). Milletler ve Hükümdarlar Tarihi. Zeki Kadri Urgan-Ahmet Temir (Çev.). İstanbul: MEB Yayınları.

Willermus, Tyrensis. (2016). Haçlı Kroniği (Historia Rerum in Partibus Transmarinis Gestarum). Ergin Ayan (Çev.). İstanbul: Ötüken Yayınları.

Zizek, S. (2009). Matrix: Ya da Sapkınlığın İki Yüzü. Bahadır Turan (Çev.). İstanbul: Encore.

\section{SONNOTE}

1 Taberi, farklı rivayetlerden alıntılar yaparak Babillerin Kudüs'e yaptıkları saldırıları sebepleriyle beraber detaylı bir şekilde anlatıyor. Bkz. Taberi, c. 2, s. 778-784; ibnü’l-Esir, c. 1, s. 198-206; Simon, Babil Kralı Nebukadnezar'ın Kudüs üzerine yaptığı üç baskını detaylı bir şekilde anlatmaktadır. Bkz. Montefiore, 2016: 43-46

2 Yazar, Müslümanların Kudüs'ü fethiyle ilgili yaptığı detaylı anlatıda Hz. Ömer'in hoşgörüsüne ve adaletine özellikle vurgu yapmaktadır; Konu ile bkz. ibnü'l-Esir, c. 2, s. 457-460

3 "Onlar: yeryüzünde fesat çıkarmayın, denildiği zaman, 'biz ancak ıslah edicileriz' diyorlar." Bakara: $2 / 11$

4 Hıttin zaferiyle ilgili detay bilgi için bkz. Şeşen, s. 94-97; ibnü’l-Esir, c. 11, s. 422-424; Mustafa, Hıttin savaşını sebep sonuçları ve savaşa giden yolun taşlarının nasıl tek tek döşendiğini detaylarıyla beraber anlatmaktadır. Bkz. S. 233-281; Sallabi de Hıttin Savaşına genişçe yer verenlerdendir: Sallabi, s. 549-593; ibni Şeddad, s. 85-91.

5 Ernoul'un önemli bir özelliği, kendisinden sonraki dönem doğulu ve batıl tarihçi ve araştırmacıların onun yazdıklarını iktibas etmeleridir. Ernoul'un insaflı yaklaşımı ve Selahaddin'e olan hayranlığı dikkatlerden kaçmamaktadır; Jackson, Müslüman tarihçilerden, Selahaddin ile Abbasi Halifesi arasındaki yazışmalardan ve Batılı tarihçi/kroniklerden alıntılar yaparak ve analizlerini ekleyerek konuya genişçe yer vermektedir; Jackson, s.331-336; Sallabi, hem doğulu Müslüman hem de Batılı tarihçi/araştırmacılardan alıntılar yaparak Kudüs'ün fethine genişçe yer vermektedir. Sallabi, s. 594-648

6 O' verdiğimiz sözü tutacağız' diye cevap verdi ve patrik de diğerleri gibi 10 Bizans sikkesi karşılığında paçayı kurtardı. (Doğru çeviri). 